\title{
Bancassurance in Tunisia: What Are the Efficiency Gains?
}

\author{
Inès Ayadi ${ }^{1}$ \\ ${ }^{1}$ Faculty of Law, Economics and Management, University of Jendouba, Tunis \& Faculty of Economic Sciences and \\ Management of Tunis, Tunis \\ Correspondence: Inès Ayadi, Assistant at the Faculty of Law, Economics and Management, University of Jendouba, \\ Tunis, and $\mathrm{PhD}$ student at the Faculty of Economic Sciences and Management of Tunis, Tunis. E-mail: \\ ayadines@yahoo.fr
}

Received: April 7, 2014

Accepted: May 6, 2014

Online Published: June 18, 2014

doi:10.5430/ijfr.v5n3p159

URL: http://dx.doi.org/10.5430/ijfr.v5n3p159

\begin{abstract}
The objective of this research is to study the impact of the sale of insurance products on the technical efficiency of Tunisian banks for the period 2003-2011 using DEA (Data Envelopment Analysis) method. Our results suggest that this efficiency is valued at a score of $60.1 \%$; commissions paid to banks by insurance companies positively affect their technical efficiency.
\end{abstract}

Keywords: bancassurance, technical efficiency, DEA (Data Envelopment Analysis), Tunisian banks

\section{Introduction}

Financial activity continues to globalize today because of deregulation. It is justified by the pursuit of financial stability and the improvement of the performance of banks. The reforms initiated in Tunisia since 1986 have enabled Tunisian banks to intensify interbank competition and to improve efficiency. This change allowed them, on the econometric level, to save a percentage of their physical or financial resources to avoid wastage. Indeed, they are more dynamic but to much remains to be done to close to international standards of efficiency.

The Tunisian banking system has known over time narrowing interest margins (Revenue conventional intermediation activities) and an increase in non-traditional activities. To maintain their competitiveness, credit institutions are required to seek a better efficiency, reconciliation between banks and insurance could provide insights into the dynamics of business relationship between them and the synergies that could be generated. In this context, Tunisian banks have received the green light for the sale of insurance products, this marriage of bank- insurance contributes to reducing costs and maximizing synergies.

It's undoubted that the banking and the insurance are two separated sectors, for along time we can easily see that today the border between them has gradually disappeared with the emergence of bancassurance model. This is defined as a strategy adopted by banks to indicate a simple distribution of insurance products through bank branches.

However, while there have been studies of the process of bancassurance, there are no other studies interested in analyzing the effects of this process on the efficiency of credit institutions. Thus, such research is important because it sheds some light on the effects of the merger between banks and insurances on the technical efficiency of the first companies.

Our objective here is twofold. In a first step, we use the DEA method to estimate the scores of technical efficiency of Tunisian banks during the period 2003-2011. In the second step, the scores of technical efficiency are used in a regression model to investigate how the sale of insurance products by banking networks influences their efficiencies. Thus, we will try to answer the following question:

\section{What is the impact of the sale of insurance products on the technical efficiency of Tunisian banks?}

This work is divided up into three parts. The first part will discuss the phenomenon of bancassurance, the second will deal with the adopted research methodology and finally, the third part presents the empirical results found along with their interpretations. 


\section{Bank Efficiency: The Bancassurance}

We can find a large number of theoretical studies dealing with organizational matters and management banks, but there are few empirical studies exploring the phenomenon of bancassurance and provide quantitative results on the efficiencies gains. These studies examine different economic reasoning to explain the success of this phenomenon. In this context, Ricci (2009) distinguishes several hypotheses:

- The information hypothesis: banks have a deep knowledge of the financial situation of clients and their attitudes towards risk, which can be a significant competitive advantage by providing produce insurance;

- The scale economies hypothesis: banks are trying to develop in this area for various reasons such as the exploitation of economies of scale, to protect their even acquisitions ...;

- The risk diversification hypothesis: banks fall within the scope of insurance activities to increase their profitability and reduce risk;

- The efficiency/scope economies hypothesis: diversification of banks in insurance sector can also be explained by the search for a high level of efficiency, operating costs and synergies.

In what follows, we will look at the last two hypotheses.

\subsection{Bancassurance: The Risk Diversification Hypotheses}

Many studies (Boyd and al (1993), Genetay and Molyneux (1998), Laderman (2000), Estrella (2001), Fields and al (2005, 2007), Chen and al (2006) and Nurullah Staikouras (2008)) suggested that the bancassurance phenomenon can be explained by the opportunity to improve the risk of bank portfolios. In this context, « Insurers' liabilities and assets are mainly long term, while banks predominantly carrymedium-term assets financed by short term liabilities. Pooling may therefore result in risk reduction....There is also a consensus that long term insurance is less risky than lending activities» (Genetay and Molyneux, (1998)).

This hypothesis of risk reduction has been tested by several empirical studies. Since the phenomenon of bancassurance is relatively recent, most of these studies were based on Mergers - Acquisitions between banks and other financial intermediaries.

Boyd and al (1993) study of Mergers - Acquisitions between banks and different categories of financial firms in the U.S market, and find that mergers with insurance companies reduce the risk (as measured by the volatility of ROA) and the probability of bank failure.

Estrella (2001) states the existence of a compromise regarding the bank diversification into other financial activities: from a management perspective the mixture firms may be more difficult, but can provide more meaningful gains in diversifying.

Indeed, a debate is centralized whether diversified firms outperform their specialized counterparts. Thus, even if we can find some similarities between banking activities and those of insurance, bancassurance can give results in gains of diversification. In this context, according to Estrella (2001) « diversification potential between banks and insurance companies still exists because of differences in the way the basic factors are combined and because the insurance sectors are themselves well-diversified».

More recently, Fields et al (2007) confirm the potential for economies of scope between the banking industry and those of insurance, suggesting that it is also interesting to observe the long-term effects of the phenomenon of bancassurance, namely ability to exploit cost synergies or revenue.

In total, banks engage in the insurance business to increase their profitability and reduce their risks. For example, Nurullah and Staikouras (2008) argue that thé best candidate to engagé with banks is insurance companies; they suggest that the phenomenon of bancassurance can be explained by an opportunity of profit improvement and reduction risk of credit institutions.

Thus, testing the hypothesis of diversification existing studies show different results. This consideration leads us to make an investment to explore other fields of research, dealing with economies of scope and efficiency.

\subsection{Bancassurance: The Efficiency/Scope Economies Hypothesis}

Scope economies occur when it is more economical to produce two (or more) together in a single company that specialized in separate units (Berger et al (1987)) products.

The definition of economies of scope refers to the cost, according to Berger et al (1987): 


$$
S C O P E E_{E f f}=\frac{T C\left(Y_{1}, 0\right)+T C\left(0, Y_{2}\right)-T C\left(Y_{1}, Y_{2}\right)}{T C\left(Y_{1}, Y_{2}\right)}
$$

Where:

TC (Y1, 0): total cost of the firm specialised in producing $\mathrm{Y} 1$;

TC $(0, Y 2)$ : total cost of the firm specialised in producing $\mathrm{Y} 2$;

TC (Y1+Y2): total cost of the joint production.

If SCOPE Eff $>0$ we have scope economies;

If SCOPE Eff $<0$ we have scope diseconomies.

Given the bancassurance phenomenon, Fields et al. (2005) calculate scope economies as follows:

$$
S C O P E_{E f f}=\frac{(F I R M 1+F I R M 2)-C O M B I N E D}{C O M B I N E D}
$$

Where:

FIRM1 and FIRM2 are pre-merger values of cost.

COMBINED is the after-merger value of cost.

This method has several advantages because it is very simple, fast and based on real data, but there is a major limitation: it can not account for changes in prices or production mix and other conditions for and after the execution of the Merger. In addition, some empirical studies show that the inefficiencies of scale or scope have a lower weight than that of technical and allocative inefficiencies of financial firms (Berger and Humphrey (1994), (1997)). Given these considerations, we can better understand the current trend observed in recent studies focusing more broadly on the concept of technical efficiency.

Finally, Tunisian banks have experienced in recent years profound changes to improve their efficiencies. These changes have resulted in operations of reconciliations between banking institutions and insurance companies giving rise to the "bancassurance". Thus, it might be interesting to provide further evidence for this key issue, with particular emphasis on the impact of the sale of insurance products on the technical efficiency of Tunisian banks.

\section{Empirical Study}

First we start by introducing some methodological elements necessary for the efficiency measure, and then we proceed to the presentation of the sample and data.

\subsection{Method DEA}

For the purpose of our study, we choose the DEA (Data Envelopment Analysis) to measure efficiency. We consider this approach as the most appropriate for the following reasons: First, this approach provides a higher degree of flexibility because it does not force us to choose a functional form of the border that links inputs and outputs imposed to all banks in our sample. Second, this method allows easy decomposition of technical efficiency into pure technical efficiency and scale efficiency and x-efficiency into technical efficiency and allocative efficiency when input prices are included. Third, the scores obtained with the DEA can obtain a aggregate score, which indicates the efficiency of each bank in relation to a set of compatible banks.

This method initially introduced by Charnes and al (1978) is a non-parametric approach, based on sample data; the data envelopment analysis involves using mathematical programming to construct an efficient virtual frontier. Operations on that border correspond to $100 \%$ efficient entities, while those outside this boundary are not totally efficient.

In this context, the DEA has been defined by Charnes and al (1978) as: "A mathematical programming model applied to observed data (That) provides a new way of obtaining empirical estimates of external relationships such as the production functions and /or efficiency production possibility surfaces that are the cornerstones of modern economics".

The DEA can be considered in two ways: input orientation and one output, the results differ depending on whether they adopt the assumption of constant returns to scale (CRS model: Constant Return to Scale) or returns scale variables (VRS model: Variable Return to Scale).

These two models are presented in the following paragraphs: 


\subsubsection{CRS Model}

Referring to Kalaitzandonakes and al (1992), we consider a sample of $\mathrm{k}$ firms where each uses $\mathrm{M}$ inputs to produce different $\mathrm{N}$ outputs.

Baskets of inputs and outputs are reduced by the DEA to a pair (input, output) qualified by Charnes and al (1978): virtual input and virtual output.

For a firm in the sample, we can obtain this measure by solving the following mathematical programming model:

$$
\begin{gathered}
\operatorname{Max}_{\alpha, \beta} \alpha Y_{i} / \beta X_{i} \\
\text { S.C } \\
\alpha Y_{j} / \beta X_{j} \leq 1 \\
\text { For } \mathrm{j}=1,2 \ldots \mathrm{k}
\end{gathered}
$$

Where:

$\alpha$ et $\beta$ are the vectors of coefficients to be estimated;

$\mathrm{Yi}$ and $\mathrm{Xi}$ respectively vectors reviewing inputs and outputs of the firm "i".

For each firm, the program maximizes the ratio of virtual output / virtual input, forcing not to exceed 1 . Thus, firms in the sample are necessarily located on or below the efficient frontier.

Charnes and Cooper (1962) have developed a process for fractional programming models for a formulation of the previous model in the following linear form:

$$
\begin{gathered}
\text { Min } \theta \\
\text { S.C } \\
\text { Y } \lambda \geq Y_{i} \\
\theta X_{i}-X \lambda \geq 0 \\
\theta \text { any, } \lambda \geq 0
\end{gathered}
$$

Where:

$\mathrm{Y}=[\mathrm{Y} 1, \ldots, \mathrm{Yk}]$ is a matrix $\mathrm{N} * \mathrm{k}$ outputs.

$\mathrm{X}=[\mathrm{X} 1 \ldots \mathrm{XK}]$ is a matrix $\mathrm{M} * \mathrm{k}$ inputs.

$\mathrm{Yi}$ and $\mathrm{Xi}$ are respectively, the vectors of inputs and outputs of the firm "i".

$\theta$ is a scalar of arbitrary sign.

$\lambda$ is a vector of dimension $\mathrm{k}$ positive coefficients to be estimated.

The optimal solution is a measure of its technical efficiency is given by the resolution of this problem.

\subsubsection{The VRS Model}

According to Coelli and al (1998): "the CRS assumption is only appropriate when all firms are operating at an optimal scale. Imperfect competition constraints on finance etc, way cause a firm to be not operating at optimal scale".

VRS model is proposed for the first time by Banker and al (1984), this model is an extension of the CRS model but takes into account situations where returns to scale are not constant. In this case, the CRS model can be modified taking into account the hypothesis of variable returns to scale. Simply add a constraint on the parameters of intensity CRS model, we obtain: 


$$
\begin{gathered}
\operatorname{Min} \theta \\
\text { S.C } \\
\mathrm{Y} \lambda \geq Y_{i} \\
\theta X_{i}-X \lambda \geq 0 \\
\theta \text { any, } \lambda \geq 0 \\
\text { N1' } \lambda=1
\end{gathered}
$$

Where:

$\mathrm{N} 1$ is a $\mathrm{N} * 1$ vector of units.

To Coelli and al (1998), a good measure of scale efficiency of a firm is the difference between the index of technical efficiency obtained through DEA type CRS and the obtained by the DEA type VRS. On the same database to get such a measure, these researchers suggest performing a DEA, CRS type and another VRS type. If there is a difference for a given firm in the efficiency index measured by these two types of DEA, this implies that the firm does not operate at an optimal scale. The scale inefficiency is the result of the difference between CRS technical inefficiency and VRS technical inefficiency.

In this work, we use the DEA input-oriented variable returns to scale. First, the input-oriented method allows us to determine the cost savings of input possible to achieve for each unit of the sample if it was as efficient as the firm best practices. Second, this method can test the hypothesis of scale variable returns that is most consistent with the environment of imperfect competition in which credit institutions operating in Tunisia, in fact, the hypothesis scale constant returns is only appropriate if the firm operates at an optimal scale, which is not always the case.

\subsection{Application}

The period of this study covers the years range between 2003-2011; the data used are taken from the annual reports of the APTBEF (Association Professionnelle Tunisienne des Banques et des Etablissements Financiers).

\subsubsection{Presentation of the Sample}

The sample consists of 10 banks which are as follows:

SOCIÉTÉ TUNISIENNE DE BANQUE (STB)

BANQUE NATIONALE AGRICOLE (BNA)

BANQUE INTERNATIONALE ARABE DE TUNISIE (BIAT)

BANQUE DE L'HABITAT (BH)

AMEN BANK (AB)

BANQUE ATTIJARI DE TUNISIE (ATTIJARI BANK)

UNION INTERNATIONALE DE BANQUES (UIB)

BANQUE DE TUNISIE (BT)

ARAB TUNISIAN BANK (ATB)

UNION BANCAIRE POUR LE COMMERCE ET L'INDUSTRIE (UBCI)

\subsubsection{Definition of Data}

Before defining the data, we choose the approach as related to banking production. And considering the operation of the Tunisian banking system where banks use deposits collected to be involved in a credit policy, it seemed more logical to adopt the approach of mediation. This approach assumes that the bank collects deposits to transform them into loans including labor and capital in the process of transformation, as opposed to the production approach which assumes that the bank uses labor and capital to produce deposits and loans.

Thus, according to the intermediation approach inputs and outputs are shown in the following table: 
Table 1. Inputs and outputs

\begin{tabular}{lc}
\hline Inputs & outputs \\
\hline . L: labor & $. Y_{1}:$ Total customer loans \\
. K: physical capital & $. Y_{2}:$ portfolio investment \\
. F: financial capital & \\
\hline
\end{tabular}

Inputs:

- $\mathrm{L}=$ number of bank employees.

- $\mathrm{K}=$ net fixed assets.

- $\mathrm{F}=$ total bank deposit.

\section{Outputs:}

- Y1 $=$ wallet discount receivable + customer loans on special resources + other loans to customers.

- $\mathrm{Y} 2=$ is a line item in the balance sheet.

\section{Empirical Results and Interpretations}

We will focus, first of all on the scores of technical efficiency of Tunisian banks in our sample, then on the study of the impact of the sale of insurance products on this efficiency.

\subsection{Technical Efficiency of Tunisian Banks}

The mean values of technical efficiency scores are outlined in the following table:

Table 2. Technical efficiency (ET) scores during the period 2003-2011

\begin{tabular}{cl}
\hline Banks & ET \\
\hline STB & 0,508 \\
BNA & 0,333 \\
BIAT & 0,634 \\
BH & 0,426 \\
AB & 0,777 \\
BAT & 0,651 \\
UIB & 0,685 \\
BT & 0,636 \\
ATB & 0,514 \\
UBCI & 0,851 \\
Medium & 0,601 \\
\hline
\end{tabular}

The global technical efficiency of the sector during the study period is estimated at an average score of $60.1 \%$, which means that the average bank in the sample is $60.1 \%$ efficient compared to the bank with the best practices. This is reflected by the fact that the average inefficiency score averages at around $39.9 \%(1-0,601)$. In other words, a bank in the sample uses an input quantity greater than $39.9 \%$ compared to the efficient bank to produce the same amount of output. This is what emerges from the definition of technical efficiency, which measures the ability of a unit to produce maximum outputs for a given level of inputs.

More personalized results, we can see a better technical efficiency for private banks (BIAT, AB, UBCI, BT, ATB, BAT and UIB) with a score of $67,8 \%$. Public banks (STB, BNA and BH) show a lower score, it is about $46,3 \%$. In this context, the differences between the levels of efficiency of public banks and private banks provisioning differences between the modes of creation and management of the assets of each type of bank. It follows that the private banks have better control costs because they can better control their spending and better supervise their activities. Indeed, they are able to improve their level of efficiency because they are motivated by maximizing their profit in order to meet the needs of shareholders and thereafter they are opting for further diversification of activities. 


\subsection{Bancassurance and Technical Efficiency of Tunisian Banks}

In this research, we selected the variable related to bancassurance service that seems better in explaining its impact on the technical efficiency of Tunisian banks. The function to be estimated is as follows:

$$
E T_{i, t}=\alpha+\beta_{1} B A N C_{t}+\varepsilon_{i, t}
$$

- BANC: This variable refers to the commissions paid to the bank by the insurance company. The latter is required to pay the bank fees which the calculation and payment terms are attached to specific conditions. These committees may, in no case, be based on the overall results of the insurance contract.

Given the unavailability of data, we approximated the commissions paid to the bank by the insurance company by the ratio:

$$
\text { BANC }=\text { Commissions } / \text { ProductNet Banking }
$$

Empirical Results and interpretations:

Table 3. The estimation results with fixed effects

\begin{tabular}{lllll}
\hline Et & Coef & Std. Err. & $\mathrm{t}$ & $\mathrm{P}>|\mathrm{t}|$ \\
\hline banc & .4081824 & .0922271 & 4.43 & $0.000^{* * *}$ \\
_cons & .0426105 & .0068204 & 6.25 & 0.000 \\
Number of obs & $=90$ & & & \\
Number of groups & $=10$ & & & \\
R-sq: withi & $=0.0094$ & & & \\
& between & $=0.2188$ & &
\end{tabular}

*** A significant at $1 \%$.

We note that the sale of insurance products through banking networks afferents positively their technical efficiency. Indeed, the agreement between banks and Tunisian insurance companies can create a synergy of activities through cross-selling between the two financial companies. The sale of insurance products through bank networks allow Tunisian banks, most of which have trained staff who are able to operate in a free market economy with major management capabilities; to cross-sell and subsequently improve their technical efficiency. Thus, banks use their brand as an additional marketing tool to attract and retain customers.

Finally, we can say that the bank efficiency can be positively affected by investment in non-traditional activities such as the sale of insurance products. These activities are likely to improve the efficiency because they do not cause a lot of expenses for banks, unlike traditional intermediation activities that require huge expenditures such as the establishment of new agencies, as well as investment in new technologies to change the methods with which customers have access to banking services and products.

\section{Conclusion}

In recent years, strong financial mutation has taken place in the Tunisian financial sector. In this context, banks have not remained without reacting and have developed a strategy of diversifying portfolio with the inclusion of insurance products. This has contributed to reconciliation between banks and insurance companies; the movement of "bancassurance" takes shape and is developed.

Thus, the purpose of this research is to study the impact of the sale of insurance products on the technical efficiency of Tunisian banks for the period 2003-2011. The results suggest that the latter is evaluated at a score of $60.1 \%$; commissions paid to banks insurance companies positively affect their technical efficiency.

Given that the development of bancassurance in Tunisia remains highly correlated with regulatory and business environment in the country, the future advocates of pronounced growth.

It should be emphasized that there are other research opportunities that can be explored. Indeed, it would be very interesting to explain the observed differences in the levels of efficiency of Tunisian banks. This determines the factors on which these banks may act to increase their efficiency levels and follow the requirements of an environment increasingly competitive. 
It should be noted that Tunisia is living a historic moment, indeed the year 2011 has been marked by the January 14 Revolution in Tunisia and its impact on the Tunisian banking sector, its weakness and immobility have become a major concern. In this context, too undercapitalized, banks no longer play their engine role in the economy. Indeed, because of insufficient capital, they are unable to increase their loan volumes and then they are unable to improve their efficiency.

\section{References}

Banker, R., Charnes, A., \& Cooper, W. (1984). Some Models for Estimating Technical and Scale Inefficiency in Data Envelopment Analysis. Management Science, 30, 1078-92. http://dx.doi.org/10.1287/mnsc.30.9.1078

Berger, A., \& Humphrey, D. (1994). Bank Scale Economies, Mergers, Concentration, and Efficiency: The U.S. Experience. Wharton School Centre for Financial Institutions, University of Pennsylvania, working paper 94-25.

Berger, A., \& Humphrey, D. (1997). Efficiency of financial institutions: international survey and direction for future research. Board of Governors of the Federal Reserve System (U.S.), Finance and Economics Discussion Series n. 1997-11.

Berger, A., Hanweck, G., \& Humphrey, D. (1987). Competitive viability in banking: scale, scope, and product mix economies. Research Papers in Banking and Financial Economics from Board of Governors of the Federal Reserve System (U.S.), n.82.

Boyd, J.H., Graham, S.L., \& Hewitt, R.S. (1993). Bank holding companies mergers with nonbank financial firms: effect of the risk of failure. Journal of Banking and Finance, 17(1), 43-63. http://dx.doi.org/10.1016/0378-4266(93)90079-S

Charnes, A., \& Cooper, W. (1962). Programming with Linear Fractional Functionals. Naval Research Logistics Quarterly, 9, 181-185. http://dx.doi.org/10.1002/nav.3800090303

Charnes, A., Cooper, W., \& Rhodes, E. (1978). Measuring the efficiency of decision-making units. European Journal of Operational Research, 2, 429-444. http://dx.doi.org/10.1016/0377-2217(78)90138-8

Chen, Z., Li, D., Moshirian, F., \& Tan, J. (2006). Does Bancassurance Add Value to Banks? - Evidence from Mergers and Acquisitions between European Banks and Insurance Companies. School of Banking \& Finance The University of New South Wales.

Coelli, T., D.S. Prasada, Rao, \& G.E. Battese. (1998). An Introduction to Efficiency and Productivity Analysis. Kluwer Academic Publishers, Boston. http://dx.doi.org/10.1007/978-1-4615-5493-6

Estrella, A. (2001). Mixing and matching: prospective financial sector mergers and market valuation. Journal of Banking and Finance, 25(12), 2367-2392. http://dx.doi.org/10.1016/S0378-4266(01)00195-9

Fields, L., Fraser, D., \& Kolari, J. (2005). What's different about bancassurance? Evidence of wealth gains to bank and insurance companies. Texas A\&M University.

Fields, L., Fraser, D., \& Kolari, J. (2007). Bidder returns in bancassurance mergers: is there evidence of synergy?. Journal of Banking and Finance, 31, 3646-3662. http://dx.doi.org/10.1016/j.jbankfin.2007.01.014

Genetay, N., \& Molyneux, P. (1998). Bancassurance. Macmillan Press.

Kalaitzadonakes, N.G., Wu, S., \& Ma, J.C. (1992). The relationship between technical efficiency and firm size revisited. Canadian Journal of Agricultural Economics, 40, 427-442. http://dx.doi.org/10.1111/j.1744-7976.1992.tb03705.x

Laderman, E.S. (2000.The potential diversification and failure reduction benefits of bank expansion into non banking activities. Federal Reserve Bank of San Francisco Working Papers.

Nurullah, M., \& Staikouras, S.K. (2008). The Separation of Banking from Insurance: Evidence from Europe. Multinational Finance Journal, 12(3/4), 157-184.

Ricci, O. (2009). Bancassurance in Europe: what are the efficiency gains? Doctoral thesis, University of Rome Tor Vergata, Italy. 